\title{
Influence of Work Stress and Leadership on Employee Performance in Special Check Posts in Automotive Industry by Using SEM-PLS
}

\author{
Maman Suherman ${ }^{1}$, Erry Rimawan ${ }^{2}$, Rahmat Hidayat ${ }^{3}$, Randi Alfian ${ }^{4}$ \\ Department of Industrial Engineering ${ }^{1,2}$, Department of Magister Management ${ }^{3,4}$ \\ Mercu Buana University, Jakarta, Indonesia
}

\begin{abstract}
This study aims to find out the effect of work stress and leadership on employee performance at PT. Astra Daihatsu Motor, this study uses a quantitative approach. Data collection was carried out by survey method by distributing questionnaires to several employees who were directly related to the test, the questionnaire consisted of several questions related to work stress, leadership and employee performance.

Because of the limitation of respondents in the study is only 26 people, the sample used in this study is a saturated sample in which the entire population is used as a sample. Data processing is performed by SEM (structural Equation Modeling) method basen on (PLS) partial least square with 2 stages of testing process that is measurement of inner model and outer model. The results show that work stress and leadership are proven to have an influence on employee performance with a value of $32.4 \%$, with the dominant factor causing work stress is a gap in communication with coworkers, while for leadership factors are leadership motivational factors for employees where the leader is able to provide Good motivation for employees in working makes the most dominant leadership factor.
\end{abstract}

Keywords:- job stress, Leadership, Employee performance.

\section{INTRODUCTION}

Japan is one country that knows about a high level of discipline, both in terms of society and in terms of productivity, therefore every product produced by the country is very well known for its quality and is one of the countries with the best quality in the world both in the industry electronics and the automotive industry. The high quality standards set by the country make this country very difficult to be penetrated by products from outside Japan specifically in Indonesia, especially in automotive products such as cars.

One of the Japanese companies that carry out the process of producing four-wheeled vehicles in Indonesia has provided vehicles that are in accordance with the standards set by Japan, so that vehicles produced by this company can be exported and marketed in Japan, the units that were successfully shipped to Japan In Tahara (Japanese PDI) a double check is done as a form of monitoring the quality of the unit, the results obtained are obtained by the company in the form of DPU (Defect Per Unit).
In order to maintain the quality of its products, the company created a special checkpoint in the designation for the vehicle, making the quality of the vehicles exported to Japan improve its quality.

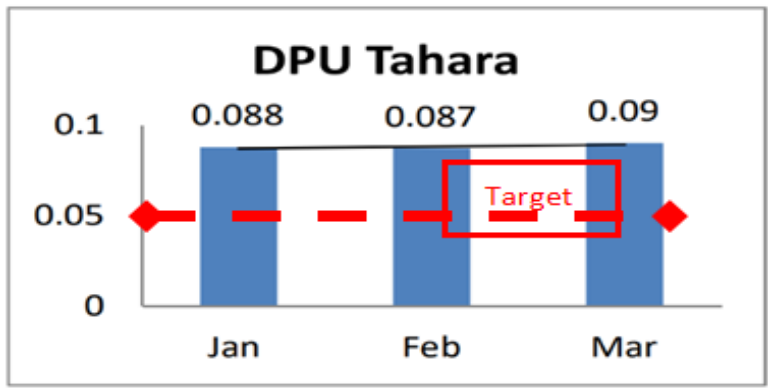

Fig 1:- DPU report last 3 months

In maintaining product quality standards, the company sets a DPU (Defect Per Unit) target of 0.05, but the results of reports in recent months indicate that the target is difficult to achieve by the company, this makes the company (management) exert excessive pressure on employees, responsibility the heavy and high pressure from management is worried that it can make employees experience stress so as to reduce the performance of these employees.

According to Robbins (2003), Stress can cause behavioral and emotional disturbances. For example depression, anxiety, drug and alcohol abuse, and work performance problems such as decreased productivity and burnout.

Besides the attitude of the leadership that sometimes gives excessive response if the target is not achieved, as one example for every defect that is missed, employees must make a counter measure as a form of accountability and form of discipline from employees so that defects that have been passed are not repeated again, the boss's attitude which is sometimes excessive can result in psychologically disturbed employees because they feel depressed due to the superior attitude of the boss so that the potential to reduce the quality of work of the employee.

The existence of work stress and excessive leadership attitudes can result in decreased performance in employees, so it needs to be anticipated so that the decline in performance can be minimized so that employee performance can be maximized. 


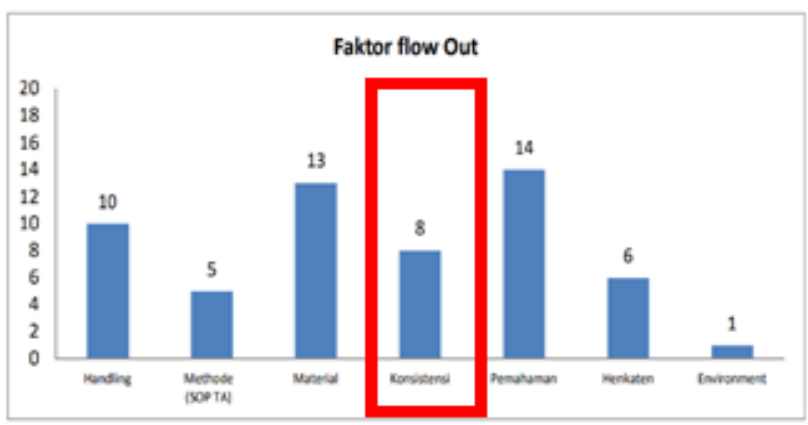

Fig 2:- Fact flow out in March

The picture above shows that around $14 \%$ ( 8 defects) comes from the consistency factor, where employees are not consistent (not in accordance with the SOP) in the checking process, the existence of such inconsistencies shows that there is a decrease in performance for employees, the decline in performance could have been caused by the factors of work stress and leadership attitudes that are too pressing, so it is important for companies to analyze the decline in performance factors.

The process of analyzing the relationship between work stress experienced by employees and the leadership attitude that is sometimes excessive, resulting in decreased employee performance can be done one of them by using SEM (Structural Equation Modeling) based on PLS (Partial Least Square) based method, PLS is a type of SEM analysis based components with formative construct properties, PLS design is intended to overcome the limitations of regression analysis with OLS (Ordinary Least Square) technique when the data characteristics are experiencing problems, such as: small data size, missing value, abnormal data distribution, and the presence of multicollinearity symptoms. OLS regression usually results in unstable data when the amount of data collected (sample) is small, or the presence of missing values or multicollinearity between predictors because these conditions can increase the standard error of the measured coefficient (Field, 2000 in Mustafa and Wijaya, 2012: 11 )

\section{REVIEW OF LITERATURE STUDY}

\section{Work stress}

Hans Selye (in Berry, 1998) defines stress as a physiological and psychological response or reaction to a stressor. Selye said that stress is a general defense reaction carried out by the body against stressors. This reaction arises due to the needs that want to be met both related to the environment or personal goals. Selye developed the concept of the physiological stress process. The physiological basis for stress is the movement of certain hormones and nervous system mechanisms. As a result stress can change the basic structure of a person. For example, an employee who is stricken with heart due to stress can cause a heart attack, and if his stomach is sensitive, it can lead to heartburn.
Beehr and Newman (in Berry, 1999), developed a model to identify and arrange all fields or components of work stress. The field model includes more than 150 variables that have been studied or stated that are stated by researchers related to stress. These variables are categorized into several groups or different fields, namely:

- Personal facets include several characteristics that have an impact on how individuals experience stress. For example a healthy personality and physique. Personal / individual character can influence interaction with the environment through personal facet variables.

- Process facets which include cognitive perceptions and evaluations of stressful situations.

- Environmental facets are related to the work environment and include demands for work roles, such as excessive roles; organizational characteristics, such as company size; and external demands, such as customers. Between individuals and organizations has consequences for the results of the process of interaction of individuals and the environment.

- Human consequences include the effects of psychological functions, such as anxiety; physical health effects, such as stomach or large intestine disorders; and the impact of open behavior such as drug use and aggression.

- Organizational consequences of stress include effects such as absence, turnover, and loss of productivity.

- Adaptive responses, following the consequences, show various attempts to deal with stress. For example, employees will make adaptive responses by seeking social support; organizations can make adaptive responses by changing work schedules; and the third part can make an adaptive response by offering treatment.

\section{Leadership}

according to Young (Kartono, 2003: 58). According to him leadership is a form of dominance based on personal ability, which is able to encourage or invite others to do something based on acceptability / acceptance by the group, and has special expertise appropriate for a particular situation. This kind of leadership is informal and always relates to group needs at special times and special places to achieve certain goals.

According to Yukl (2005: 9) in addition to the characteristics of a good leader must have the influence and important role in doing the following:

- Motivate members to achieve goals

- Mutual trust and cooperation between members

- Learning and sharing of new knowledge between members

- Organization of work activities

- Achievement of objectives and strategies achieved

- Development of trust and skills among members 


\section{Employee performance}

According to As'ad (1998) performance is the result achieved by someone according to the measurement that applies to the work in question. According to Withmore (1997 in Mahesa 2010) stated that performance is an expression of a person's potential in fulfilling their responsibilities by setting certain standards. Performance is one of the total collections of work available to workers.

According to McCormick and Tiffin (in Suharto \& Cahyono, 2005) explained that there are two variables that affect performance.

- Individual variables Individual variables consist of experience, education, gender, age, motivation, physical condition, personality.

- Situational Variables Situational variables involve two factors :

$\checkmark$ Social and organizational factors, including: policy, type of training and experience, wage system and social environment.

$\checkmark$ Physical and occupational factors, including: work methods, settings and conditions, work equipment, workspace settings, noise, irradiation and temperature.

\section{$>$ Partial least square-structural equation modelling}

Partial Least Square (PLS) based Structural Equation Modeling (SEM) is a multivariate statistical technique that can handle multiple response variables and explanatory variables at the same time. This analysis is a good alternative to the method of multiple regression analysis and principal component regression, because this method is more robust or invulnerable. Robust means that the parameters of the model do not change much when new samples are taken from the total population (Geladi and Kowalski, 1986).

Partial Least Square is a predictive technique that can handle many independent variables, even though multicollinearity occurs between these variables (Ramzan and Khan, 2010).

According to Wold, PLS is a powerful analysis method because it is not based on many assumptions or conditions, such as normality and multicollinearity tests. The method has its own advantages, among others: data does not have to be multivariate normally distributed. Even indicators with a scale of data categories, ordinal, intervals to ratios can be used. Another advantage is that the sample size does not have to be large.

At this stage the testing of the suitability of the model will be carried out through various criteria from the inner model and the outer model there are 3 parts in PLS.

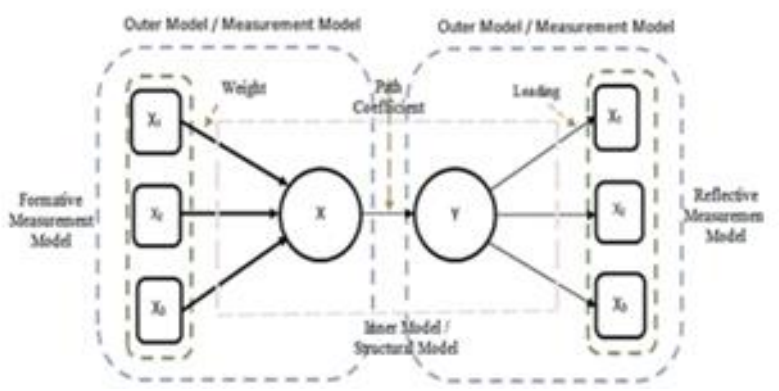

Fig 3:- PLS path modeling

First path modeling At this stage a model of relationship between variables is made where the indicators of each variable are also entered into the model as shown below, where variable $\mathrm{X}$ has 3 indicators namely $\mathrm{x} 1$, $\mathrm{x} 2$ and $\mathrm{x} 3$ and variable $\mathrm{Y}$ has 3 indicators namely $\mathrm{y} 1, \mathrm{y} 2$ and $\mathrm{y} 3$.

The second is the measurement model, also called the outer model, connects all manifest variable or indicator with its latent variable. In the PLS framework, one variable manifest can only be connected with one latent variable. All manifest variables are associated with one latent variable called a block. Thus every latent variable have manifest variable blocks. A block must contain at least one indicator.

And third is the structural model, which is also called the inner model, all latent variables are connected with one another based on theory of substance. The latent variable is divided into two, namely exogenous and endogenous. Exogenous latent variable are variable cause or variable without being preceded by other variables with arrow marking towards to other variables (endogenous latent variable).

\section{METHODOLOGY}

\section{A. Types of research}

This type of research is a cross sectional study, a study that studies the dynamics of the relationship or correlation between risk factors and impact, the approach taken is observation or data collection at the same time (point time approach). Each research subject was only observed once and the time span was measured against the character status or subject variables at the time of the study. Research subjects do not have to be observed at the same time. This design can clearly know which is the process and outcome, as well as the clarity of the correlation of cause and effect (Notoatmodjo, 2002).

Put simply, Cross sectional can be understood as a study that studies several observational variables at one time at the same time to look for a causal relationship between independent variables on the dependent variable.

Respondents in this study employees are employees who carry out the process at the special check post consisting of 26 respondents, saturation sampling is a sampling technique when all members of the population are used as samples. This is often done if the population is relatively small, less than 30 peopleThis type of research is 
a cross sectional study, a study that studies the dynamics of the relationship or correlation between risk factors and impact, the approach taken is observation or data collection at the same time (point time approach). Each research subject was only observed once and the time span was measured against the character status or subject variables at the time of the study. Research subjects do not have to be observed at the same time. This design can clearly know which is the process and outcome, as well as the clarity of the correlation of cause and effect (Notoatmodjo, 2002).

Put simply, Cross sectional can be understood as a study that studies several observational variables at one time at the same time to look for a causal relationship between independent variables on the dependent variable.

Respondents in this study employees are employees who carry out the process at the special check post consisting of 26 respondents, saturation sampling is a sampling technique when all members of the population are used as samples. This is often done if the population is relatively small, less than 30 people

\section{B. Data Processing Method}

\section{Path Modeling}

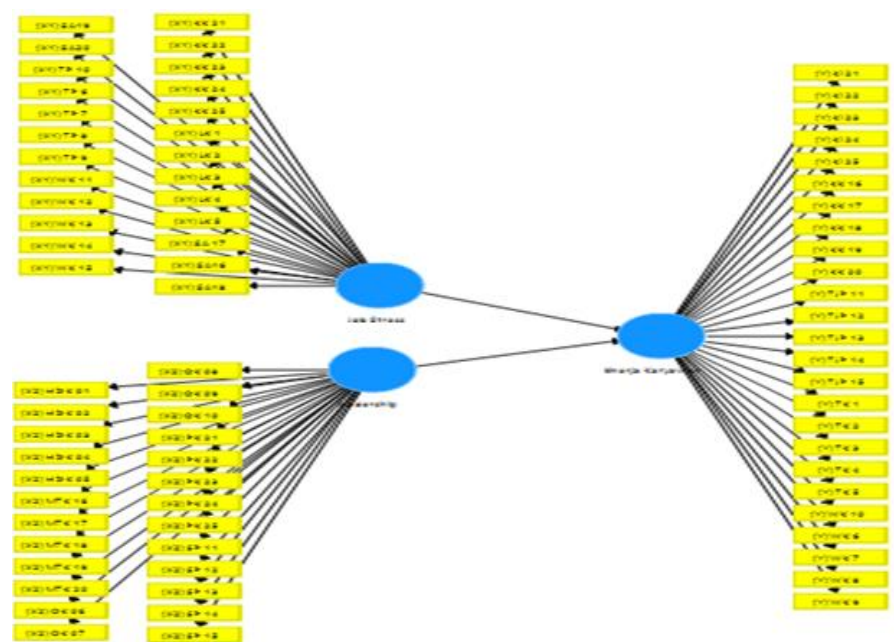

Fig 4:- Path Modeling

The hypothesis for this research is :

H1: the effect of work stress on employee performance

$\mathrm{H} 2$ : leadership influence on employee performance

H3: the influence of work stress and leadership on employee performance

\section{Outer model}

\section{$>$ Validity test}

- Convergent validity

Correlation between reflexive indicator scores and latent variable scores. Expected loading factor value> 0.7, but according to Mindra (2008) loading values 0.5 - 0.6 can be tolerated, as long as the research model is still in development stage with a measurement scale and the number of indicators per variable is not large, ranging from three to with seven indicators. Based on these criteria if there is a loading factor below 0.50 it will be dropped from the model.

\section{- Discriminant validity}

The measurement of discriminant validity uses criteria submitted by Fornell-Larcker and "cross loadings". FornellLarcker's postulate states that a latent variable shares more variants with the underlying indicator than with other latent variables. This is interpreted statistically, then the value of AVE for each latent variable must be greater than the highest value of $\mathrm{r} 2$ with the value of other latent variables.

The second criterion for discriminant validity is the 'loading' for each indicator is expected to be higher than the respective 'cross-loading'. If the Fornell-Larcker criterion assesses discriminant validity at the construct level (latent variable), then 'cross-loading' is possible at the indicator level.

\section{$>$ Reliability Test}

- Construct reliability and validity

According to Abdillah and Hartono (2015) Cronbach's Alpha is a statistical technique used to measure internal consistency in instrument reliability tests or psychometric data. Whereas Composite Reliability (CR) is a statistical technique for testing the same reliability as Cronbach's Alpha. To be able to say a reliable construct, the Cronbach Alpha value must be> 0.6 and the Composite Reliability value must be> 0.7, Average Variance Extracted (AVE) is used to measure the amount of variance that can be captured by the construct compared to the variance caused by measurement errors. AVE value must be greater (>0.5).

\section{Inner Model \\ $>R$-square $\left(R^{2}\right)$}

According to Ghozali and Latan (2015) Changes in the value of $\mathrm{R}$ Square can be used as a reference to explain the effect of exogenous variables on whether endogenous variables have an influence. $\mathrm{R}$ Square values of $0.75,0.50$ and 0.25 can be concluded whether the model is strong, moderate or weak 


\section{Hypothesis}

Hypothesis test $(\beta, \gamma$, and $\lambda)$ performed with Bootstrap resampling method developed by Geisser and Stone. The test statistic used is the $\mathrm{t}$ statistic or $\mathrm{t}$ test ( $\mathrm{t}$ count must be> 1.96) 1.96 at the error level of $5 \%$. if $\mathrm{T}$ statistic $>1.96$, the hypothesis is accepted.

\section{RESULT}

\section{A. Outer model,}

\section{$>$ Validity Test}

- Convergent validity,

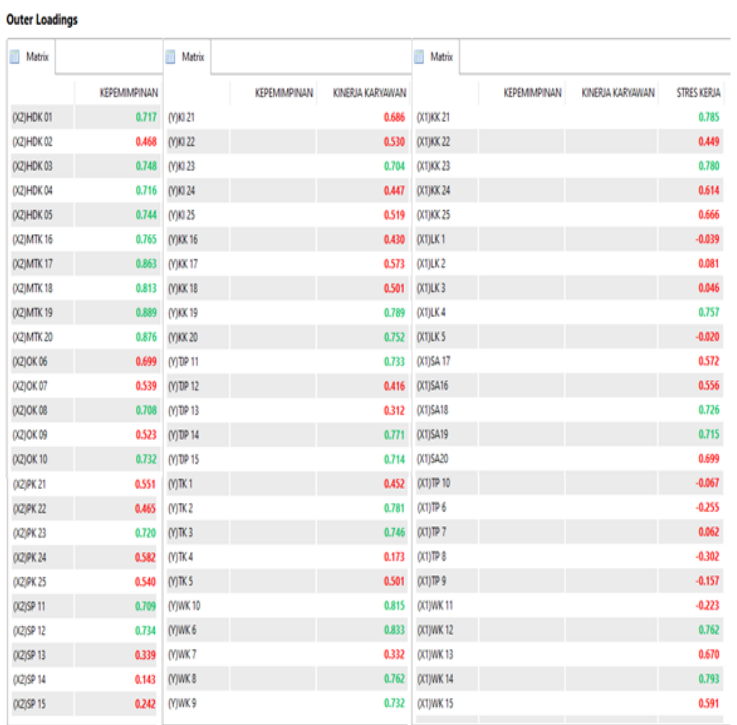

Fig 5:- $1^{\text {st }}$ Test of Outer Loading

For variable $\mathrm{X} 1$ there are 14 and $\mathrm{X} 2$ there are 7 valid indicators while for $\mathrm{Y}$ indicator there are 13 valid indicators, so from the whole indicator only 37 are valid indicators, for those invalid indicators, they must be dropped from the model and tested again for see the loading factor.. From the table above, it can be seen that the loading factor value of all the indicators is 1 that is red, namely (Y) KL 23

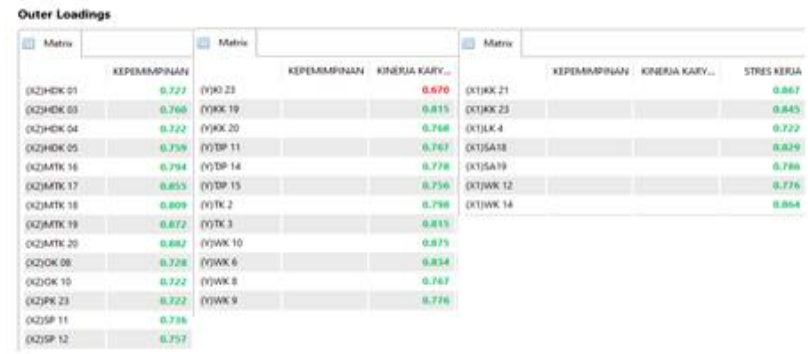

Fig 6:- Results of the $2^{\text {nd }}$ outer loading loading measurement

With a value of 0.670 , therefore the indicator must be dropped again and retested until all of the indicators are above 0.7 .

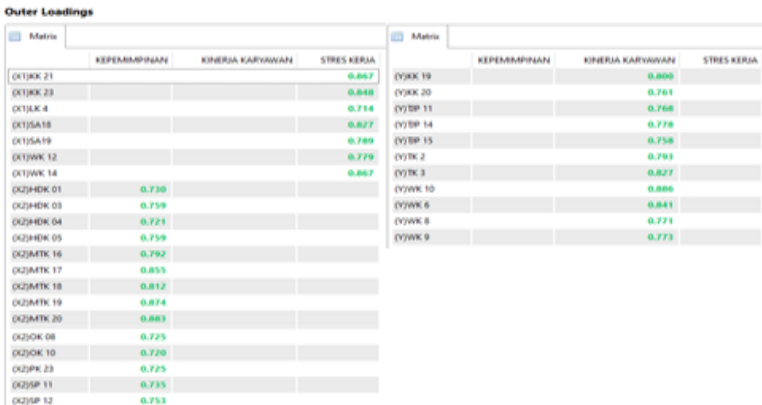

Fig 7:- $3^{\text {rd }}$ test of Outer loading measurement results

From the results of the retest after the indicator has been dropped, it can be seen the results of all the indicators are already above 0.7

\section{- Discriminant validity}

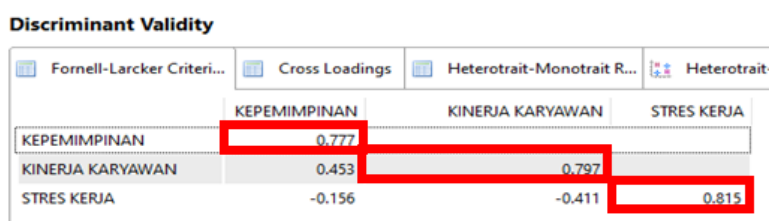

Fig 8:- Measurement results fornell larcker criterion

The value for fornell larcker criterion where for leadership indicators worth 0.777, for employee performance valued at 0.797 and for work stress valued at 0.815 where the value of the three variables have the highest value compared with the value of cross loading.

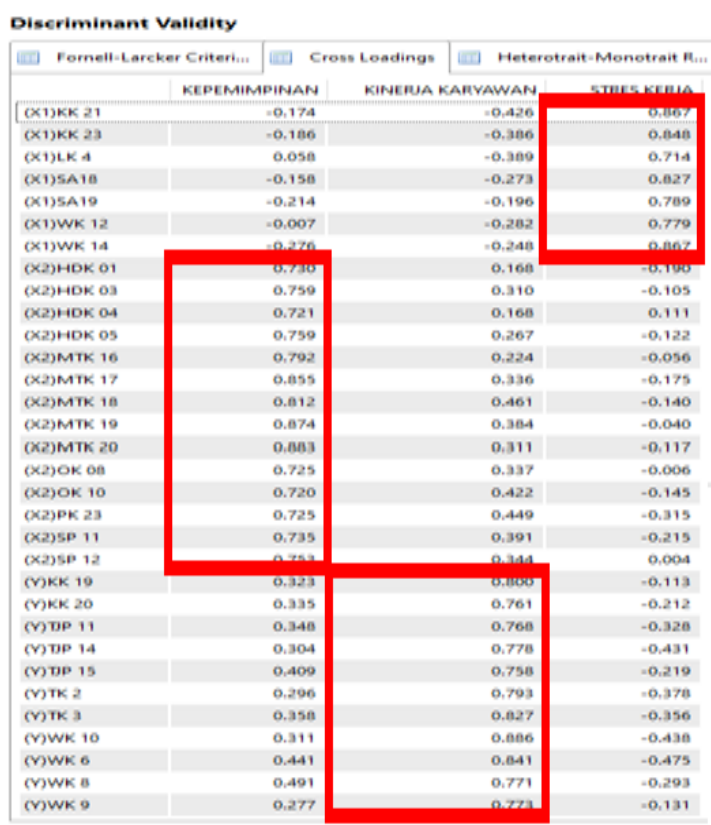

Fig 9:- cross loading measurement results

On the table can be seen that the loading indicator on each of these variables has the highest value compared to the value of cross loading. 
Uji reliabilitas

- Construct reliability and validity

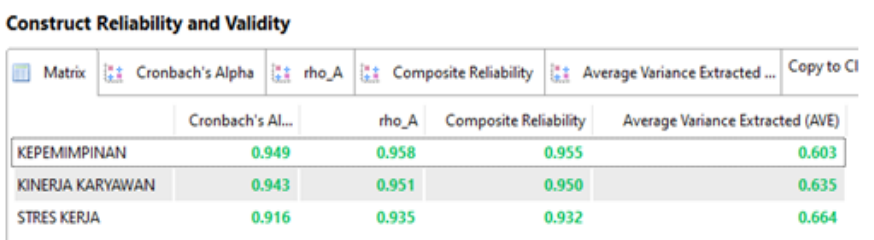

Fig 10:- results of measurements of construct reliability and validity

The reliability measurement results show that Cronbach's Alpha has $>0.6$, Composite Reliability $>0.7$ and AVE value> 0.6. Means the results are reliable.

\section{B. Inner Model \\ $>R$-square $\left(R^{2}\right)$}

R Square
\begin{tabular}{|l|r|r|r|}
\hline Matrix & Rat R Square & ift. R Square Adjusted & \\
\cline { 2 - 4 } & R Square & R Square Adjusted \\
\hline KINERUA KARYAWAN & 0.324 & 0.265 \\
\hline
\end{tabular}

Fig 11:- R-Square measurement results

From the table above, the R-Square value is 0.265 , which means the influence of $\mathrm{X} 1$ (work stress), X2 (leadership) on $\mathrm{Y}$ (employee performance) does have an influence, but the effect is weak, because the value is very far from number 1 . Or if we change it into a percentage then only $26.5 \%$ of variables $\mathrm{X}$ and $\mathrm{X} 2$ can affect the variable $\mathrm{Y}$, so the effect is considered lemah.

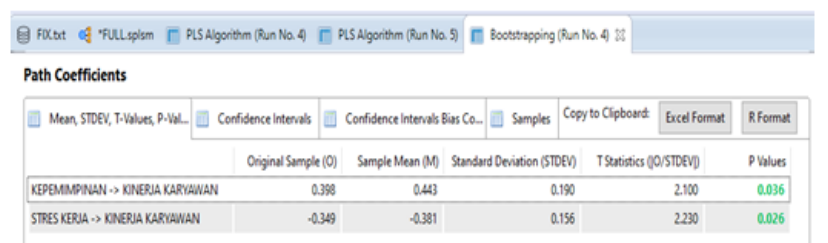

Fig 12:- Bootsraping test results

\section{Hypothesis}

In the test table above, the T-Statistic value for the influence of work stress on employee performance is 2,230 , meaning that the hypothesis is accepted because the TStatistic value is above 1.96 with a p-value significance value below 0.05 which is 0.026 , meaning that the relationship between Job stress - proven employee performance. As for the T-Statistics score for the relationship between employee's employee leadership performance is 2,100, it means that the hypothesis is accepted, because the T-Statistics value is above 1.96 with a significance value of p-value below 0.05 , which is 0.036 , meaning that the relationship between leadership erja performance employees are also proven.

\section{CONCLUSION}

With an original sample value of $-0,349$ and a TStatistic value of 2,042, it means that it is true that work stress has an influence on employee performance and a negative effect.

$>$ with an original sample value of 0.398 and a T-Statistic value of 2.100 , meaning that it is true that leadership has an influence on employee performance and the influence is positive.

$>$ With an R-Square value of 0.324 , it means that work and leadership stress does have an influence on employee performance but at a weak level.

\section{REFERENCES}

[1]. Rimawan, E, Suroso D, and Wahyudin. 2020. International Journal of Advanced Science and Technology. 29(3) 2694-2713.

[2]. Ananto, Reza. 2014. Analisi Pengaruh Gaya Kepemimpinan, Motivasi dan disiplin Kerja terhadap Kinerja Pegawai (Studi Empiris pada PT DHL Forwarding Semarang Branch. Skripsi. Semarang: Universitas Diponegoro Semarang.

[3]. Dzulkifli, Muhammad. 2013. Pengaruh Gaya Kepemimpinan, Motivasi, Disiplin Kerja, Kompetensi dan Budaya Organisasi terhadap Kinerja Pegawai Direktorat Budidaya dan Pascapanen Holtikultura Pasar Minggu Jakarta Selatan. Skripsi. Jakarta: UIN Syarif Hidayatullah.

[4]. Robbins, Stephen P. 2003. Prinsip-Prinsip Perilaku Organisasi. Jakarta: Erlangga.

[5]. Robbins, Stephen $P$ dan Timoty A. Judge. 2008. Organizational Behavior, Thirteenth Edition. New Jersey: Pearson Prentice-Hal Inc.

[6]. Berry, M.L. 1998. Psychology at Work: an Introduction to Industri and Organizational Psychology. Boston: McGraw-Hill Book Co.

[7]. Yukl, Gary. 2010. Leadership in Organizations (7th edition). Jakarta: PT. Indeks.

[8]. Kartono, Kartini, 2003, Pemimpin dan Kepemimpinan (Apakah Kepemimpinan Abnormal Itu). Jakarta: P.T Raja Grafindo Persada.

[9]. As'ad, Moh, 1998. Psikologi Industri : Seri Ilmu Sumber Daya Manusia, Yogyakarta : Liberty.

[10]. Mahesa, D. 2010. Analisis Pengaruh Motivasi dan Kepuasan kerja Terhadap Kinerja Karyawan Dengan Lama Kerja Sebagai Variabel Moderating (Sstudi pada PT. Coca Cola Amatil Indonesia (Centaral Java)). Semarang: Universitas Diponegoro.

[11]. Suharto, \& Cahyo., B. 2005. Pengaruh Budaya Organisasi, Kepemimpinan dan Motivasi Kerja Terhadap Kinerja Sumber Daya Manusia, di sekretariat DPRD Propinsi Jawa Tengah, JRBI. Vol. 1, No.1, januari 2005: 13-30.

[12]. Geladi P, Kowalski BR. 1986. Partial least squares regression: A tutorial. Analitycal Chimica Acta. 185:1-17. 
[13]. Ramzan, S, \& Khan, M. I. 2010. Dimension Reduction and Remedy of Multicollinearity Using Latent Variable Regression Methods. World Applied Science Journal. 8 (4): 404-410

[14]. Notoatmodjo. S. 2002. Metodologi Penelitian Kesehatan. Jakarta: Rineka Cipta.

[15]. Mindra, Sukma dan Teguh Erawati. 2014. pengaruh Earning Per Share, ukuran perusahaan/ size, Profitabilitas dan Leverage terhadap nilai perusahaan pada perusahaan manufaktur yang terdaftar di BEI periode 2009-2011. Jurnal Akuntansi.Vol 2.No 2.Yogyakarta: Universitas Sarjanawiyata Taman Siswa Yogyakarta.

[16]. Abdillah, W, Hartono. 2015. Partial Least Square (PLS). Yogyakarta : CV. Alfabeta. 